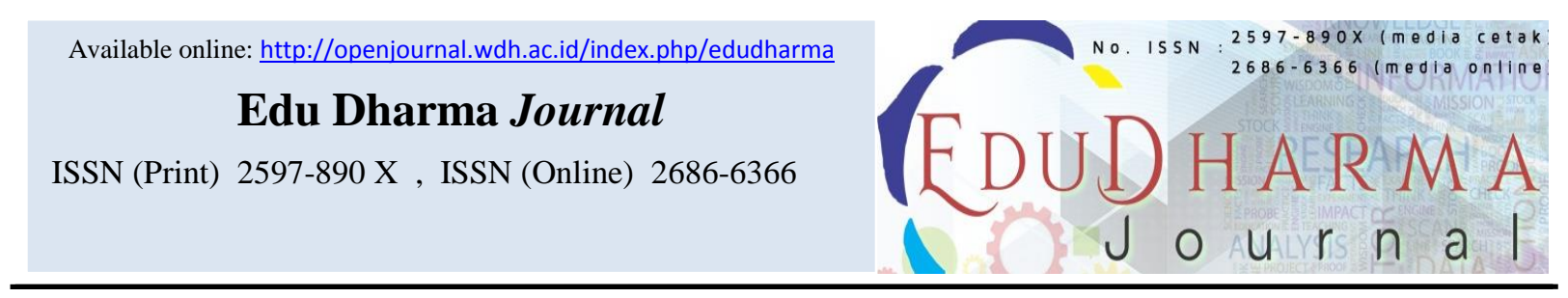

\title{
KORELASI PERILAKU KESEHATAN DAN EFEK SAMPING OAT DENGAN KEPATUHAN PENDERITA TUBERKULOSIS PARU DI PUSKESMAS KERANGGAN TANGERANG SELATAN
}

\author{
Dewi Fitriani ${ }^{1 *}$, Ida Listiana ${ }^{2}$, Rita Dwi Pratiwi ${ }^{3}$ Mulia $^{4}$ \\ ${ }^{1,2,3}$ STIKes Widya Dharma Husada Tangerang, Jalan Padjajaran No. 1 Pamulang Tangerang Selatan Banten, 15417 \\ ${ }^{4}$ Mahasiswa Prodi S1 Keperawatan, STIKes Widya Dharma Husada Tangerang, \\ Jalan Padjajaran No. 1 Pamulang Tangerang Selatan Banten, 15417
}

\begin{tabular}{|c|c|}
\hline ARTICLE INFORMATION & $A B S T R A C T$ \\
\hline $\begin{array}{l}\text { *Dewi Fitriani } \\
\text { Name } \\
\text { E-mail: dewifitriani@wdh.ac.id }\end{array}$ & $\begin{array}{l}\text { According to WHO in 2015, Indonesia was in the top } 3 \text { of } 22 \\
\text { countries in the world with a TB burden of } 10.0 \% \text {. In 2019, in the } \\
\text { Keranggan Puskesmas area, South Tangerang city, there were } \\
110 \text { pulmonary TB cases per 100,000 population. Pulmonary TB } \\
\text { cases were found in the Puskesmas Keranggan, South Tangerang }\end{array}$ \\
\hline $\begin{array}{l}\text { Keywords: } \\
\text { Level of compliance; } \\
\text { Health behaviors; } \\
\text { Side effects level of adherence; } \\
\text { Pulmonary tuberculosis sufferers. }\end{array}$ & $\begin{array}{l}\text { city, as many as } 78 \text { cases. The purpose of this study was to } \\
\text { determine the correlation of health behavior and side effects with } \\
\text { the level of compliance of patients with pulmonary tuberculosis } \\
\text { in the intensive phase at Puskesmas Keranggan in 2019. The } \\
\text { design of this study was cross-sectional analytic using } \\
\text { questionnaires and observational interviews. The population in } \\
\text { this study were all patients with pulmonary TB from September } \\
\text { 2019-January 2020, namely } 62 \text { people. The statistical analysis } \\
\text { used was the chi-square test. The results showed that there was a } \\
\text { correlation between the level of adherence to treatment of } \\
\text { pulmonary tuberculosis patients with good health behavior with } \\
\text { p-value = O.O26. But there is no correlation with the side effects } \\
\text { of OAT obtained p-value = 0.212. It is suggested that it can be } \\
\text { used as an ingredient in knowing the Correlation of Health } \\
\text { Behavior and Side Effects of OAT with the level of compliance of } \\
\text { Patients with Pulmonary Tuberculosis in the Intensive Phase at } \\
\text { Puskesmas Keranggan in } 2020 . \text {. }\end{array}$ \\
\hline $\begin{array}{l}\text { Kata Kunci: } \\
\text { Tingkat kepatuhan; } \\
\text { Perilaku Kesehatan; } \\
\text { Efek Samping; } \\
\text { Penderita tuberkulosis paru }\end{array}$ & $\begin{array}{l}\text { A B S T R A K } \\
\text { Menurut WHO, tahun } 2015 \text { Indonesia berada di posisi } 3 \text { dari } 22 \\
\text { negara dengan beban penderita TB sebesar } 10,0 \% \text {. Pada tahun } \\
\text { 2019, di wilayah Puskesmas Keranggan kota Tangerang Selatan } \\
\text { terdapat sebanyak } 110 \text { kasus TB paru/100.000 penduduk. } \\
\text { Insidensi TB paru banyak ditemukan di wilayah Puskesmas } \\
\text { Keranggan kota Tangerang Selatan yaitu sebanyak } 78 \text { kasus. } \\
\text { Tujuan penelitian ini adalah Mengetahui Korelasi Perilaku } \\
\text { Kesehatan dan Efek Samping dengan tingkat kepatuhan } \\
\text { penderita tuberkulosis Paru pada fase intensif di Puskesmas } \\
\text { Keranggan tahun 2019. Desain penelitian menggunakan } \\
\text { analitik cross sectional. Pengambilan data penelitian } \\
\text { menggunakan kuesioner dan wawancara observasional. Populasi } \\
\text { dalam penelitian ini adalah seluruh penderita TB paru periode } \\
\text { September 2019-Januari } 2020 \text { yaitu } 62 \text { orang. Analisis statistik } \\
\text { yang digunakan adalah uji chi-square. Hasil penelitian }\end{array}$ \\
\hline
\end{tabular}




\begin{tabular}{|l|l|l|}
\hline & $\begin{array}{l}\text { menunjukkan ada Korelasi antara tingkat kepatuhan berobat } \\
\text { dengan perilaku kesehatan pada penderita TB paru dengan nilai } \\
\text {-value =0,026. Tetapi tidak terdapat Korelasi dengan efek } \\
\text { samping OAT dengan nilai } p \text {-value =0,212. Disarankan dapat } \\
\text { dijadikan sebagai bahan dalam mengetahui adanya Korelasi } \\
\text { Perilaku Kesehatan dan Efek Samping OAT dengan tingkat } \\
\text { kepatuhan Penderita Tuberkulosis Paru pada Fase Intensif di } \\
\text { Puskesmas Keranggan Tahun 2020. }\end{array}$ \\
\hline & This is an open access article under the CC-BY-NC-SA license. \\
\hline & & C) () (2) (2) \\
\hline
\end{tabular}


PENDAHULUAN

Penyakit tuberkulosis atau dengan istilah TB paru adalah penyakit infeksi yang disebabkan oleh bakteri Mycobacterium Tuberculosa yang menyerang parenkim paru-paru (Soemantri,2007). TB Paru merupakan salah satu penyumbang angka kematian tertinggi baik di negara berkembang maupun negara maju. Jumlahnya selalu meningkat disetiap tahunnya, WHO menjelaskan pada tahun 2013 kasus TB diperkirakan 8,6 juta jiwa, 1,1 juta (13\%) dengan koinfeksi HIV dan kasus kematian TB mencapai 410 ribu (Kementerian Kesehatan Republik Indonesia, 2014). Menurut Laporan WHO, tahun 2015 menjelaskan dari 22 Negara di dunia bahwa Indonesia menempati posisi 3 besar dengan beban TB mencapai 10\%. Dan pada saat ini telah timbul kedaruratan baru dalam penanganan TB Paru, yaitu dengan TB MDR (Multi Drug Resistance) atau Resisten Obat (WHO Global Tuberculosis Report, 2015).

Seiring berjalannya waktu dimana adanya peningkatan jumlah penderita TB paru yang disebabkan oleh salah satunya adalah kemiskinan pada kelompok masyarakat di indonesia, beban sosial seperti tingkat pengangguran yang tinggi, ketidakpatuhan pasien dalam program pengobatan sampai tuntas, tidak memadainya tatalaksana kasus dilapangan dan timbulnya resistensi berganda. Pengobatan TB paru ini memerlukan waktu yang panjang, dimana pengobatan paling pendek 6 bulan sehingga menyebabkan kurangnya kepatuhan pengobatan pasien yang mempengaruhi keberhasilan terapi (Kementerian Kesehatan Republik Indonesia, 2014).

Beberapa faktor yang mempengaruhi kepatuhan berobat penderita TB paru diantaranya efek samping pengobatan, pendidikan pasien dan juga pendapatan keluarga yang kurang (Erawatyningsih et al, 2009). Menurut Hayes (2016), perlu dilakukan tindakan evaluasi tentang kepatuhan penggunaan obat TB paru agar tingkat keberhasilan terapi dapat tercapa. Adapun dampak dari ketidakpatuhan pasien dalam mengkonsumsi obat dapat merugikan pasien sendiri dan resisten terhadap obat (Hayes et al, 2016; Pratiwi et al, 2020 ).

Berdasarkan hasil penelitian yang dilaksanakan oleh Prameswari et al pada tahun 2015 disimpulkan bahwa semakin patuh pasien dalam pengobatan maka angka keberhasilan tujuan terapi pasien semakin tinggi pula. Menurut data yang dapat dari Puskesmas Keranggan sebanyak 36.742 dengan 2 kelurahan dengan jumlah 
kasus sebanyak 75, jumlah keberhasilan pengobatan yang sembuh 27 responden,yang lengkap 42 responden, jadi SR ( Success rate $=92 \%$ ). Dari data hasil pendataan pada tahun 2018 di Puskesmas Keranggan Kota Tangerang selatan didapatkan penderita TB paru 70 dan yang memiliki efek samping OAT sebanyak 34 orang diantaranya DO (Drop Out) 3,meninggal 3, dan yang dirujuk ke RS 3 karena ada efek samping setelah minum Obat TB, HIV positif 2. Sedangkan dari Januari 2019 sampai dengan bulan september 2019 didapat penderita TB paru sebanyak 78 orang,dengan jumlah penemuan kasus meningkat sebanyak 83 (CDR $76 \%$ ),dengan BTA positif 24, BTA neg 55,Extra paru 6,anak 14 yang mengalami efek samping 11 orang, DO (Drop out) 5, Meninggal 2.

\section{METODE}

Menerapkan jenis penelitian analitik, desain cross sectional dan dilaksanakan bulan September 2019Januari 2020. Populasi dalam penelitian ini yaitu 62 responden dan tehnik sampling yang digunakan yaitu Total sampling. Untuk Analisis Univariat berdasarkan variabel penelitian yang diteliti Usia, Jenis Kelamin, Pekerjaan dan Penghasilan ditampilkan dalam bentuk distribusi dengan interpretasi secara deskriptif. Untuk Analis bivariat dilakukan perbandingan antara dua variabel yaitu variabel independen dan dependen untuk membuktikan adanya korelasi antara dua variabel diatas digunakan uji statistic Chi-square dengan menggunakan derajat kepercayaan $95 \%$.

\section{HASIL}

\section{A. Analisis Univariat}

Tabel.1. Distribusi Frekuensi Responden Berdasarkan Usia Pasien Tuberkulosis Paru di Puskesmas Keranggan Kota Tangerang Selatan $(n=62)$

\begin{tabular}{ccc}
\hline Usia ( Th ) & Frekuensi & Persentase (\%) \\
\hline $0-5$ & 9 & 14,5 \\
\hline $5-16$ & 9 & 14,5 \\
\hline $17-35$ & 19 & 30,7 \\
\hline $36-45$ & 8 & 12,9 \\
\hline $46-55$ & 7 & 11,3 \\
\hline $56-65$ & 9 & 14,5 \\
\hline$>65$ & 1 & 16 \\
\hline Total & $\mathbf{6 2}$ & $\mathbf{1 0 0}$ \\
\hline
\end{tabular}


Berdasarkan Tabel.1 karakteristik tahun hampir setengahnya yaitu

responden dari penelitian ini berjumlah sebanyak 30,7\%, dan sebagian kecil

62 jumlah responden tertinggi yaitu yaitu pada usia $>65$ tahun hampir tidak responden didapati yang usia 17-35 ada yaitu sebanyak $1,6 \%$.

Tabel.2. Distribusi Frekuensi Responden Berdasarkan Jenis Kelamin Pasien Tuberkulosis Paru di Puskesmas Keranggan Kota Tangerang Selatan ( $\mathrm{n}=62)$

\begin{tabular}{lcc}
\hline Jenis Kelamin & Frekuensi & Persentase (\%) \\
\hline Perempuan & 32 & 51.6 \\
\hline Laki-laki & 30 & 48,4 \\
\hline & $\mathbf{6 2}$ & $\mathbf{1 0 0}$
\end{tabular}

Berdasarkan Tabel.2 karakteristik dari responden penelitian ini berjumlah 62 responden didapati yang berjenis kelamin perempuan lebih dari setengahnya yaitu $51,6 \%$, dan hampir setengahnya berjenis kelamin laki- laki sebanyak $48,4 \%$.

Tabel 3. Distribusi Frekuensi Responden Berdasarkan Pendidikan pada pasien Tuberkulosis Paru di Puskesmas Keranggan Kota Tangerang Selatan ( $\mathrm{n}=62)$

\begin{tabular}{ccc}
\hline Pendidikan & Frekuensi & $\begin{array}{c}\text { Persentase } \\
(\boldsymbol{\%})\end{array}$ \\
\hline Tidak tamat SD & 15 & 24,2 \\
\hline SD & 12 & 19,4 \\
\hline SLTP & 11 & 17,7 \\
\hline SLTA & 23 & 37,1 \\
\hline Akademi/Sarjana & 1 & 1,61 \\
\hline
\end{tabular}

Berdasarkan Tabel 3, sebanyak 62 dan hampir tidak ada berpendidikan responden didapati yang berpendidikan Akademi./sarjana yaitu dengan persentase SLTA lebih dari setengahnya yaitu $37,1 \%, \quad 1,61 \%$.

Tabel 4. Distribusi Frekuensi Responden Berdasarkan Tingkat Kepatuhan Pengobatan Penderita Tuberkulosis Paru di Puskesmas Keranggan Tangerang Selatan ( $\mathrm{n}=62)$

\begin{tabular}{lcc}
\hline Tingkat Kepatuhan & Frekuensi & $\%$ \\
\hline Tidak Patuh & 8 & 12,9 \\
\hline Patuh & 54 & 87,1 \\
\hline Total & 62 & 100 \\
\hline
\end{tabular}


Berdasarkan Tabel.4 karakteristik dari responden penelitian ini berjumlah 62 responden didapati yang patuh hampir seluruh responden yaitu $87,1 \%$.

Tabel 5. Distribusi Frekuensi Responden Berdasarkan Perilaku Kesehatan pada Penderita Tuberkulosis Paru di Puskesmas Keranggan Tangerang Selatan $(\mathrm{n}=62)$

\begin{tabular}{ccc}
\hline Perilaku kesehatan & Frekuensi & Persentase (\%) \\
\hline Tidak Baik & 8 & $12,9 \%$ \\
\hline Baik & 54 & $87,1 \%$ \\
\hline Total & 62 & 100 \\
\hline
\end{tabular}

Berdasarkan Tabel 5. karakteristik dari responden penelitian ini dari jumlah 62 responden didapat yang berperilaku kesehatan tergolong baik hampir seluruhnya yaitu 54 orang dengan persentase $(87,1 \%)$, dan sebagian kecil berperilaku kesehatan tidak baik sebanyak 8 orang dengan persentase $(12,9 \%)$.

\section{B. Analisa Bivariat}

Tabel 6. Korelasi Perilaku Kesehatan Dengan Tingkat kepatuhan Pengobatan penderita TB Paru di Puskesmas Keranggan Tangerang Selatan $(n=62)$

\begin{tabular}{|c|c|c|c|c|c|c|c|}
\hline \multirow{4}{*}{$\begin{array}{l}\text { Perilaku } \\
\text { Kesehatan }\end{array}$} & \multicolumn{4}{|c|}{ Tingkat Kepatuhan } & & & \multirow{4}{*}{ P Value } \\
\hline & \multicolumn{2}{|c|}{ Tidak Patuh } & \multicolumn{2}{|c|}{ Patuh } & \multirow{2}{*}{\multicolumn{2}{|c|}{ Total }} & \\
\hline & & & & & & & \\
\hline & $\mathrm{n}$ & $\%$ & $\mathrm{n}$ & $\%$ & $\mathrm{n}$ & $\%$ & \\
\hline Tidak Baik & 3 & 4,8 & 5 & 8 & 8 & 12,9 & \\
\hline Baik & 5 & 8,1 & 49 & 79 & 54 & 87,1 & 0.026 \\
\hline Total & 8 & 12,9 & 54 & 87,1 & 62 & 100 & \\
\hline
\end{tabular}

Berdasarkan Tabel 6, Hasil uji statistik diperoleh nilai $\mathrm{P}=0,026$ maka dapat disimpulkan ada perbedaan proporsi kejadian Tingkat kepatuhan cenderung patuh dengan perilaku kesehatan yang tidak baik dan perilaku yang baik yang cenderung patuh (ada hubungan yang signifikan antara perilaku kesehatan dengan tingkat kepatuhan). Berdasarkan hasil uji analisis bivariat antara variabel 
perilaku kesehatan dengan tingkat

lebih kecil dari $\mathrm{p}=0,05$.

kepatuhan didapatkan $\mathrm{p}=0,026$

Tabel 7. Korelasi efek samping OAT dengan Tingkat Kepatuhan di Puskesmas Keranggan Tangerang Selatan $(n=62)$

\begin{tabular}{|c|c|c|c|c|c|c|c|}
\hline \multirow{3}{*}{ Efek Samping } & \multicolumn{4}{|c|}{ Tingkat Kepatuhan } & \multirow[t]{2}{*}{ Total } & & \multirow[t]{3}{*}{ p value } \\
\hline & \multicolumn{2}{|c|}{ Tidak Patuh } & \multicolumn{2}{|c|}{ Patuh } & & & \\
\hline & $\mathbf{N}$ & $\%$ & $\mathbf{N}$ & $\%$ & $\mathbf{N}$ & $\%$ & \\
\hline Tidak Ada & 0 & 0 & 9 & 14,5 & 9 & 14,5 & 0.212 \\
\hline Ada & 8 & 12,9 & 45 & 72,6 & 53 & 85,5 & \\
\hline Total & 8 & 12,9 & 54 & 87.1 & 62 & 100 & \\
\hline
\end{tabular}

Beradasarkan Tabel 6. dari hasil uji statistik di peroleh nilai $\mathrm{p}=0,212$ maka dapat disimpulkan ada perbedaan proporsi kejadian tingkat kepatuhan, cenderung patuh dengan efek samping yang tidak ada dan ada efek samping yang cenderung patuh tidak ada hubungan yang signifikan antara efek samping dengan tingkat kepatuhan).

Berdasarkan hasil uji analisa bivariat antara variabel perilaku kesehatan dengan tingkat kepatuhan didapatkan $\mathrm{p}=0,212$ lebih besar dari $\mathrm{p}=0,05$.

\section{PEMBAHASAN}

Pada penelitian ini mayoritas responden yang terbanyak adalah usia 17-35 tahun hampir setengahnya yaitu sebanyak $30,7 \%, \quad$ dimana karakteristik Usia akan mempengaruhi Kasus kejadian TB Paru dikarenakan semakin Usia seseorang menua maka semakin rentan terkena penyakit TB paru ini. Dimana Faktor Usia dalam kejadian penyakit TB Paru merupakan factor risiko tinggi akan terjadi pada usia ini. Untuk Usia ini kasus TB paru seperti kurva normal terbalik yaitu tinggi ketika awal dan akan menurun saat usia di atas 2 tahun hingga usia dewasa.

Berdasarkan Survei Prevalensi Tuberkulosis pada tahun 2013-2014, kasus di Indonesia sebesar 759/100.000 penduduk berusia diatas 15 tahun. Prevalensi TBC dengan BTA positif sebesar 257 per 100.000 penduduk berusia 15 tahun keatas. Dan pada rentang usia dewasa seseorang lebih rentan terkena penyakit TB karena pada usia dewasa seseorang lebih cenderung aktif dalam bekerja dan melakukan interaksi 
sosial yang aktif sehingga lebih mudah keterpaparan terhadap penyakit TB Paru akan lebih besar (Kementrian Kesehatan, 2019 dalam Pratiwi dkk, 2019)

Menurut hasil RISKESDAS pada tahun 2018 dijelaskan bahwa kejadian penyakit TB Paru pada kaum laki-laki $20 \%$ lebih tinggi dibanding pada perempuan. Selain itu penderita TB Paru pada kaum perempuan memiliki insidensi kematian yang tinggi. Mobilitas dan aktivitas yang tinggi pada laki-laki memperbesar kemungkinan kontak dengan orang lain sehingga meningkatkan tingginya angka penularan pada kaum laki-laki ditambah dengan kebiasaan mengkonsumsi alkohol dan bergadang juga dapat menurunkan sistem imunitas tubuh. Selain itu lakilaki sebagian besar memiliki kebiasaan merokok yang akan menyebabkan gangguan pada paru dan akan meningkatkan risiko TB paru sebanyak 2,2 kali lipat. Perbedaan angka ini dikarenakan perempuan lebih waspada terhadap penyakit karena takut menular kepada keluarga atau anaknya (Fitriani dan Ayuningtyas, 2019).
Korelasi perilaku kesehatan dengan tingkat kepatuhan Berdasarkan hasil uji statistik diperoleh nilai $\mathrm{P}<0,05$ ( $\mathrm{p}=0,026$ ) maka dapat disimpulkan ada perbedaan proporsi Tingkat kepatuhan yang patuh dengan perilaku kesehatan yang tidak baik dan perilaku yang baik (ada korelasi yang signifikan antara perilaku kesehatan dengan tingkat kepatuhan) menunjukan bahwa perilaku kesehatan dengan kategori baik memiliki tingkat kepatuhan yaitu 90,7\%, dibandingkan dengan kategori tidak baik sebesar $62,5 \%$.

Penelitian ini sejalan dengan penelitian Seniantara dkk pada tahun 2018 yang disimpulkan bahwa terdapat korelasi antara efek samping OAT dengan kepatuhan minum obat. Hal ini disimpulkan bahwa semakin berat efek samping Obat TB Paru maka pasien semakin tidak patuh untuk minum obat.

Hasil penelitian tidak sejalan dengan penelitian Anissa (2012) yang dilaksanakan di Kabupaten Lima Puluh Kota, dimana disimpulkan bahwa tidak ada korelasi yang bermakna antara petugas kesehatan 
dengan kepatuhan penderita TB Paru.

Berdasarkan hasil wawancara yang dilaksanakan diketahui bahwa petugas kesehatan tidak seluruhnya memberikan penyuluhan mengenai jadwal minum obat dan penjelasan tentang pengobatan, pencegahan penularan dirumah dan pentingnya PMO dalam pengawasan minum obat.

Untuk Korelasi Efek samping OAT dengan tingkat kepatuhan menunjukan proporsi korelasi efek samping OAT dengan tingkat Kepatuhan yang baik, Responden yang tidak ada efek samping cenderung patuh, dengan tingkat kepatuhan yang patuh sebesar $100 \%$ dibandingkan dengan responden yang ada efek samping dengan tingkat kepatuhan yang patuh yaitu sebesar $84,9 \%$. Berdasarkan hasil uji analisis bivariat antara variabel efek samping dengan tingkat kepatuhan didapatkan $\mathrm{p}-$ Value $=0,212$ dimana hasil $\mathrm{p}>0,05$, yang dapat disimpulkan bahwa tidak terdapat korelasi bermakna antara efek samping dengan tingkat kepatuhan dengan. Berdasarkan uraian diatas peneliti berpendapat bahwa bahwa tidak ada korelasi yang bermakna antara efek samping OAT
(Obat Anti Tuberkulosis) di Puskesmas Keranggan Tangerang selatan dengan tingkat kepatuhan pengobatan responden.

\section{KESIMPULAN}

1. 1. Teridentifikasi responden dari 62 responden berdasarkan usia didapatkan hasil Usia 17-35 th hampir setengahnya yaitu persentase $30,7 \%$, karakteristik berdasarkan Jenis Kelamin didapati yang berjenis kelamin perempuan lebih dari setengahnya yaitu persentase $51,6 \%$. Berdasarkan karakteristik pendidikan maka pendidikan SLTA lebih dari setengahnya yaitu dengan persentase $37,1 \%$.

2. 2.Teridentifikasi Korelasi Perilaku Kesehatan dengan tingkat kepatuhan penderita tuberkulosis menunjukan bahwa perilaku kesehatan kategori baik memiliki tingkat kepatuhan 87,1 $\%$,

3. 3. Teridentifikasi Korelasi Tingkat kepatuhan dengan perilaku kesehatan yang Pada Pasien TB Paru pada fase intensif di Puskesmas Keranggan Kota Tangerang Selatan. Dari hasil uji statistik diperoleh nilai $p$-value $=$ 0,026 maka disimpulkan bahwa ada perbedaan proporsi kejadian Tingkat 
kepatuhan cenderung patuh dengan perilaku kesehatan yang baik.

4. Teranalisis hasil uji statistik diperoleh nilai $p$-value $=0,212$, maka disimpulkan bahwa tidak terdapat

\section{DAFTAR PUSTAKA}

Annisa, F. 2012. Hubungan Tingkat Pengetahuan Penderita,Peran Petugas Kesehatan Dan Peran Pengawas Menelan Obat (Pmo) Dengan Kepatuhan Penderita Tb Paru Dalam Pengobatan Di Puskesmas Muaro Bungo Lima Puluh Kota Tahun 2012 (Skripsi) . Padang : Fakultas Kesehatan Masyarakat Universitas Andalas. onesearch.id $>$ Records $>$ IOS2

Erawatyningsih, Erni. 2009. Faktor Faktor Yang Mempengaruhi Ketidakpatuhan Berobat Pada Penderita Tuberkulosis Paru.jurnal kedokteran,25 (Vol.3)

Fitriani, D., \& Ayuningtyas, G. 2019. Hubungan Antara Peran Keluarga Sebagai Pengawas Minum Obat (Pmo) Dengan Tingkat Kepatuhan Pasien Tb Paru Terhadap Program Pengobatan Di Wilayah Puskesmas Serpong 1 Kota Tangerang Selatan. Jurnal penelitian dan pengabdian masyarakat, 3(2), 17-23

Hayes et al. 2016. Hubungan Kepatuhan Terhadap Keberhasilan Terapi Di Instalasi Rawat Jalan Balai Besar Kesehatan Paru Masyarakat korelasi bermakna antara efek samping OAT dengan tingkat kepatuhan Pada Pasien TB Paru pada fase intensif di Puskesmas Keranggan Kota Tangerang Selatan,

Surakarta. Artikel B imamala,FRS Suharsono.

Prameswari, Puspa. Halim, Auzal. Yustika, 2015. Lisa. Tingkat Kepatuhan Penggunaan Obat Pada Pasien Tuberkulosis Di Rumah Sakit Mayjen H.A.Thalib Kabupaten Kerinci. https://jsfk.ffarmasi.unand.ac.id>jsfk> view

Pratiwi, R.D., Fitriani, D. and Betty, B., 2020. Penggunaan media komunikasi android apps dalam optimalisasi pengawas minum obat (PMO) terhadap tingkat kepatuhan dan kesembuhan penderita tuberkulosis paru. Holistik Jurnal Kesehatan, 14(4), pp.624-641.

Seniantara, I. K., Ivana, T., \& Adang, Y. G. 2018. Pengaruh Efek Samping Oat (Obat Anti Tuberculosis) Terhadap Kepatuhan Minum Obat Pada Pasien Tbc Di Puskesmas. Jurnal Keperawatan Suaka Insan (JKSI), 3(2), 1-12:

Soemantri. 2007. Keperawatan Medikal Bedah. Jakarta : Salemba medika

WHO Global Tuberculosis Report. 2015. Jakarta. PDIP. Strategi Nasional Pengendalian TB Indonesia 20102014. 